\title{
THE ROLE OF AIRPORTS IN THE TOURIST MARKET DEVELOPMENT ON THE EXAMPLE OF SPAIN
}

\author{
KRZYSZTOF WIDAWSKI, ${ }^{1}$ PIOTR OLEŚNIEWICZ, ${ }^{2}$ \\ ANNA ZARĘBA, ${ }^{3}$ AliCJA KRZEMIŃSKA ${ }^{4}$ \\ ${ }^{1}$ University of Wroclaw, POLAND \\ e-mail: krzysztof.widawski@uwr.edu.pl \\ 2 University School of Physical Education in Wroclaw, POLAND \\ e-mail: piotr.olesniewicz@awf.wroc.pl \\ ${ }^{3}$ University of Wroclaw, POLAND \\ e-mail: anna.zareba@uwr.edu.pl \\ ${ }^{4}$ University of Wroclaw, POLAND \\ e-mail: alicja.krzeminska@uwr.edu.pl
}

RECEIVED
ACCEPTED
JEL
CLASSIFICATION

KEYWORDS

ABSTRACT
10 August

15 November

N74, R11, R41, Z32

air transport, airports, tourism, Spain

The role of air transport in the development of tourism has been crucial for the last decades. Among others, it opens the tourist market for new destinations, and induces the development of tourist infrastructure and tourist services. The main purpose of the article was to investigate the influence of air transport on tourism in one of the world's most important tourist destinations - Spain. A brief historical background was provided. The authors then analyzed the functioning of the most important part of the infrastructure, i.e. airports in Spain, in the context of passenger transport, tourist motivations or preferred tourist destinations. The study indicates that Spain, located peripherally on the European continent and receiving more than 60 million international tourists per year, owes its success to the air connections. New destinations appeared on the tourist map of Spain that had earlier been less accessible for international and national tourists. Tourism in Spain is based in $80 \%$ on air transport, which is the reason for its dynamic development.

\section{Introduction}

The role of air transport in the development of tourism has been crucial during the last decades. Among the most important changes mentioned in the literature, there is opening of the tourist market for new destinations. Taking 
into account the fact that the major share of the emissive tourist market belongs to Europe and the United Stated, the long-haul intercontinental destinations would not have developed if not for air transport, which considerably shortens the time of the journey (Kaczmarska, 2014; Kozak, 2009; Pender, Sharpley, 2008; Wyrzykowski, Marak, 2010). An important issue is also the political decision to deregulate the aviation market, which reduced the transport costs and opened it for new clients. Since charter and low cost carriers (LCC) appeared, air transport has adopted the dominant role in the transport services in tourism (Aguiló, Rey, Roselló, Torres, 2007; Kowalczyk, 2001; Rey, Myro, Galera, 2010). It is worth mentioning as well that air transport seems one of the cheapest, thus increasing the accessibility of tourist regions. Airport cost is considerably lower than that of the net of roads and rail trails connecting a region with the world. This disproportion increases even more with the distance between the regions that emit and receive tourist traffic.

The report "The economic \& social benefits of air transport" published by ATAG (2005) points at the most important economic advantages brought about by air transport. First of all - aviation helps create a global net of transport, which initiates business development and mass tourism in the world. It is stressed that air transport dominates in tourism, influencing the sustainable development of developing countries. The local society profits from tourism as it increases their economic status by creating new work places, increasing income and (more indirectly) forming the attitude of care for the local natural and cultural environment.

The significance of air transport in the development of tourism is emphasized by Kowalczyk (2013), who points at the following major influence zones:

- appearance of tourist values,

- development of tourist infrastructure,

- development of tourist services,

- enhancement of communicational accessibility (p. 62).

Considering all the above mentioned facts, the authors investigated the influence of air transport on tourism in one of the world's most important tourist destinations - Spain. This constitutes the main purpose of the article. The process should start with a brief history of the development of this kind of transport in tourism, as well as the development of tourist traffic in Spain. A more detailed analysis will be dedicated to the functioning of the most important part of the infrastructure, i.e. airports in Spain, in the context of passenger transport. Special attention is paid to the seven most important tourist airports in Spain.

\section{Histopy of aip transpopt in tourism}

Air transport in tourism has emerged relatively recently. Its beginning dates back to the years after World War II; 1950 is accepted as the symbolic date of mass tourism beginning, as then the number of international arrivals reached 25 million (Wyrzykowski, Marak, 2010). Many factors contributed to the phenomenon, although the most important seems the possibility to use military airplanes from the war period in the civil transport.

The 1950s and 1960s were a period of dynamic development in the aviation industry. Airstrips were indurated and later illuminated. Terminals for passengers and luggage handling were built. Airports started to offer additional services for tourists, like restaurants or duty-free shops. The most important technological change was the introduction of jet engines and supporting infrastructure like the fuel distribution system (Pietrzakowski, 2012).

In 1970, a wide-bodied aircraft Boeing 747-100 was introduced, thus increasing the capacity of passenger airplanes. In 1967, Boeing 737 could accommodate only 130 persons, while the capacity of the next versions 
increased to almost 300 seats (Boeing 767) (Kowalczyk, 2001). The constructional changes in airplanes decreased the exploitation costs. Therefore, the reduction of the final cost made air transport much more attractive for tourism. Among the most important consequences, there is the development of intercontinental tourism, which would not be possible without air transport (Kowalczyk, 2001).

Apart from the technological factors influencing the development of this means of transportation, also political, economic or logistic changes exert their impact on the growth of tourism. An important moment in the development of mass tourist air transport was the introduction of charter flights, based on an agreement of leasing a plane by a tour-operator. A political issue considerably changing the market of passenger air transport in tourism was the famous Airline Deregulation Act from 1978, issued in the USA. A similar idea appeared in the European law in 1997 (Koźlak, 2008; Pijet-Migoń, 2012). The consequence of the deregulation was a global opening of air transport for free market economy. The effects could be noticed almost immediately. Generally, up till now, the $21^{\text {st }}$ century has been the period of air transport - also in tourism, all around the world.

\section{Tourist traffic in the aip transport context}

The recent 12 years have been an excellent period in the development of air transport in tourism. Although air transport revolutionized tourism in the mid-1960s, enabling its mass character, it started to play the leading role only in the current century (Lareu, 1994). For statistical purposes, the United Nations World Tourism Organization (UNWTO) investigates the 4 main kinds of transport (air, road, rail and sea) and their usage in tourism. For the last several decades, the main share has belonged to road and air transport. For more than 20 years, these have constituted around $90-93 \%$ of the total tourist traffic, although their share varies. In 2004, air transport occupied the $1^{\text {st }}$ place for the first time, with $45 \%$ of the total number of tourists using a plane as a means of transportation, outpacing road transport, which attained $43 \%$ (UNWTO, 2006). Four years later, air transport was chosen by more than $50 \%$ of the total number of tourists for the first time. This influenced the global development of tourism. Therefore, many new tourist regions have appeared and others observed dynamic development. Since 2002, a constant increase of tourist traffic in the Asia-Pacific region has been noted. According to the UNWTO statistic data, in 2015 , almost $25 \%$ of tourists migrated toward this destination. In total, there were 279.2 million of arrivals. At the very beginning of the recent decade, the number of visits was around 56 million (around $13 \%$ in the world tourist traffic). When one considers the fact that the major share of tourists are Europeans and Americans traveling by plane, the conclusion seems obvious: air transport has played and still plays a crucial role in the development of tourism in the Asia-Pacific region (the one with the highest dynamics of increase in the last decade).

In the case of Spain, the most important tourist markets are: Great Britain, Germany, France, Italy, Scandinavian countries and Benelux (Figure 1).

Tourists from these countries usually use air transport when visiting the Iberian Peninsula. Spain as a tourist country (in 2015 , it was visited by $68,215,000$ tourists) owes its success to air transport. In $2014,79.8 \%$ of tourists arrived here by plane, $18.4 \%$ by road transport, $1.3 \%$ entered Spain via sea, and $0.5 \%$ used rail connection (http:// estadisticas.tourspain.es). 


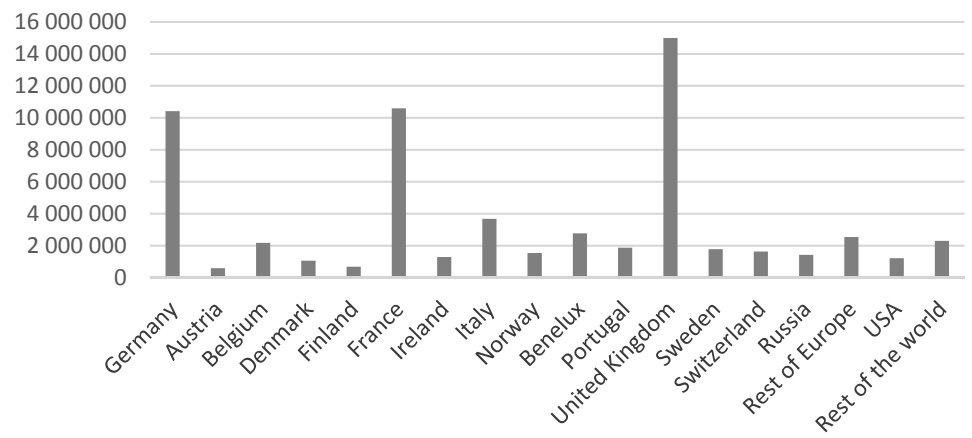

Figure 1. Tourist traffic in Spain according to countries, 2014

Source: http://estadisticas.tourspain.es.

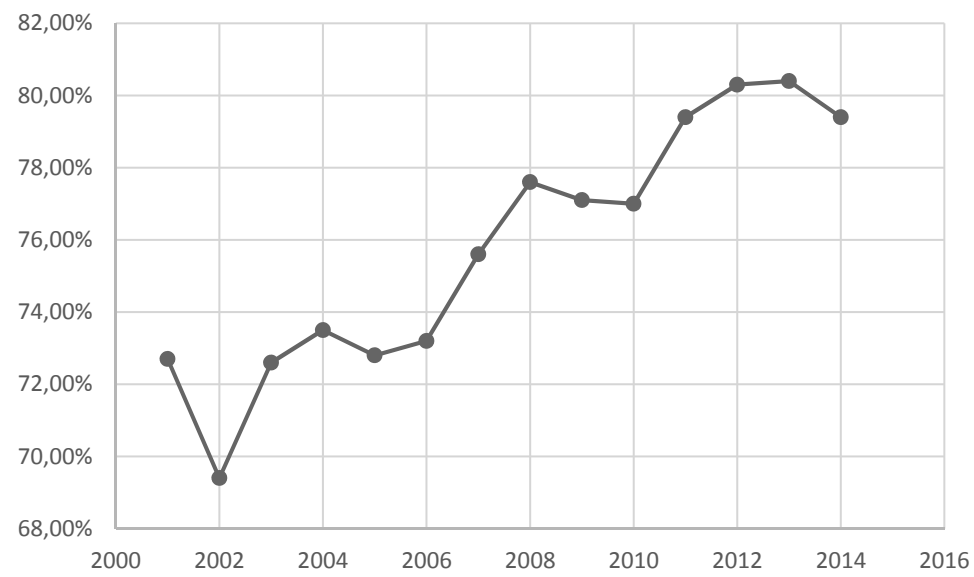

Figure 2. Share of tourists using air transport in Spain in the $21^{\text {st }}$ century

Source: http://estadisticas.tourspain.es.

In the $21^{\text {st }}$ century, air transport remains the main means of transportation in Spain, especially for international tourists. The temporal decreases in its popularity were observed in 2002 (an effect of WTC terrorist attack) and in the period of 2008-2010 (as a result of the world financial crisis) (Figure 2).

\section{Communicational infrastructure - Spanish airports}

It is worth to analyze tourism functioning in Spain in the context of air transport. Its efficiency depends on the proper organization of its infrastructure. There are 48 passenger airports in Spain, 2 of which serve only helicopters (http://www.aena.es). The enterprise managing the Spanish airports - Aena Aeropuertos (Aena Airports) - classifies the airports into three main groups in order to investigate the competitive environment. These are:

- regional airports, 
- tourist airports,

- hubs (CNMC, 2014, p. 102).

In the first group, there are airports competitive owing to their geographical localization. They are usually characterized by a limited international passenger traffic. Their main task is to communicate the region with the outside world. The number of passengers there is higher than 700,000 per year. Among such airports are Bilbao, Seville, Santiago de Compostela, Tenerife Nord, Santander, La Palma, Asturias or La Coruna. Some small regional airports with passenger traffic smaller than 700,000 are Granada, Vigo, Albacete, Badajoz, Salamanca, Pamplona, San Sebastian, Hierro or Gomera.

The airports of the second group directly compete with the regional ones. The number of passengers here also overcomes 700,000 per year and, more importantly, the share of international traffic is high, usually exceeding $50 \%$. These airports compete on the international market. Some are very popular among tourists, e.g. Tenerife South, Alicante-Elche, Malaga-Costa del Sol, Palma de Mallorca, Gran Canaria, Menorca, Murcia or Jerez.

Taking into account the size and complexity of passenger traffic, the most important group of airports are hubs. Their characteristic feature is considerably higher passenger traffic than it could be expected when considering their geographical location. There is also significant international passenger traffic, and airports in this group serve both as final destination airports and as transfer ones. The share of connecting passengers here is substantial.

According to the Aena resources, only 2 airports (Madrid and Barcelona) receive a number of passengers considerable enough to be called hubs: Madrid-Barajas (ca. 25\% of connection passengers) and El Prat in Barcelona ( $5 \%$ of connection passengers). Madrid is a typical hub. Another important feature in the hub group is the number of international long distance connections. In the case of Madrid-Barajas, such connections outside the European Union (EU) reach ca. $25 \%$, and for Barcelona they make $8 \%$. As for national connections, the percentage of the passenger share is almost similar in both - 30\% for Madrid and $29 \%$ for Barcelona. The share for the EU and the Schengen zone is $45 \%$ for Madrid and 63\% for Barcelona (CNMC, 2014).

The competitiveness of tourist airports is an important issue. First of all, it depends on the location. This element can gain or lose significance depending on tourists' motivation to use a particular airport. This factor is vital for business and visiting friends or relatives (VFR) travels and remains less weighty for those going on holidays or for leisure - in this case, a wide range of transport services counts. It is worth stressing that airports offering charter flights and receiving LCC companies are considered more attractive.

\section{Main airports in Spain in the tourism service}

Among the 48 airports operated by Aena, 7 are of international importance. Each of them gathers passenger traffic of ca. 10 million persons or more. These are: Madrid-Barajas, Barcelona-El Prat, Palma de Mallorca, MalagaCosta del Sol, Gran Canaria, Alicante-Elche and Tenerife South (http://www.aena.es).

In 2011, the highest number of passengers (nearly 50 million) were served by the biggest Spanish airport - Madrid-Barajas. It is also the only airport from the presented group which noted a clear decrease of the traffic (around 20\%) in 2013 (the time of crisis in the Spanish economy). The other airports avoided such a loss (Figure 3). The drop in the number of passengers experienced by the Gran Canaria airport equaled 100,000 persons (ca. 1\%) and thus should rather be called a stagnation. It is worth stressing that all the airports that registered a constant growth of traffic are located in areas called tourist regions (zonas turisticas) by the Instituto Nacional de Estadistica (INE). It seems that just owing to their location and to the fact that they operate on the tourist market they avoided 
the decrease in the tourist traffic, as can be observed in the passenger flow at Barcelona-El Prat, Palma de Mallorca or Malaga-Costa del Sol. The only mismatched airport is Madrid-Barajas.

In the analysis of the tourist traffic statistics, it is interesting to look at the passengers' origin. In all of the described airports, the international character of the passenger flow dominates (Figure 4); in 2015, Spain was visited by more than 60 million international tourists.

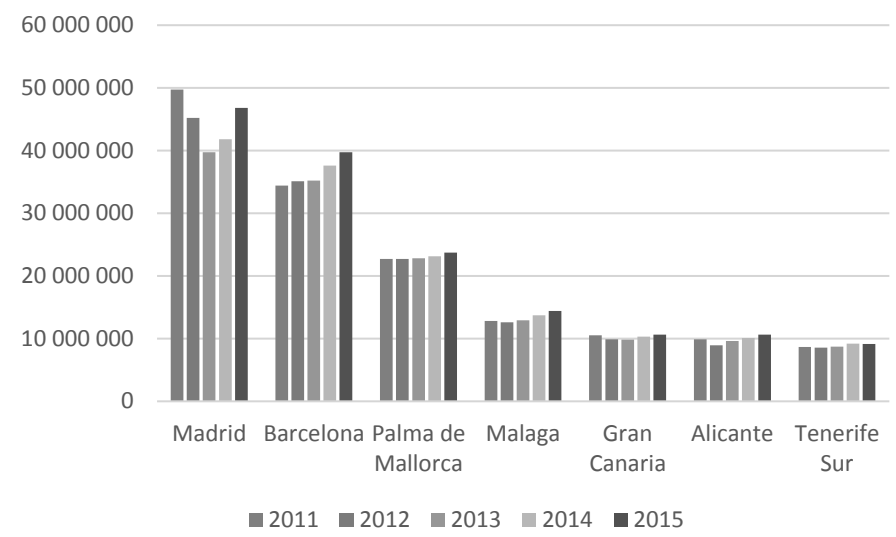

Figure 3. Number of passengers at the biggest Spanish airports, 2011-2015

Source: http://www.aena.es.

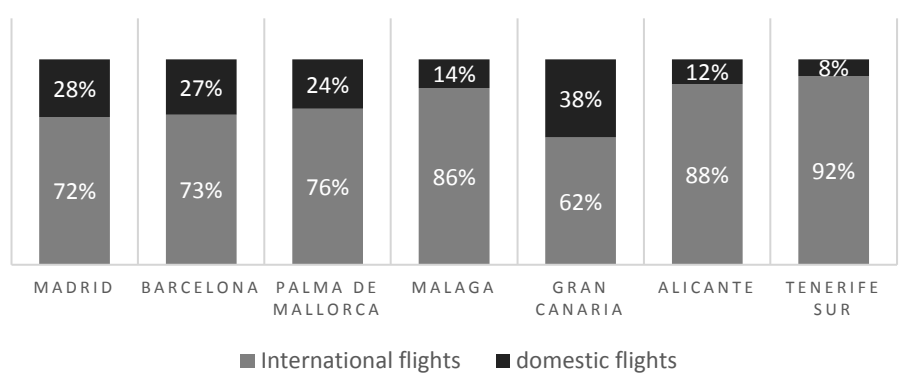

Figure 4. Tourist traffic in 2015

Source: http://www.aena.es.

Another issue to be investigated is the connectivity of the analyzed airports.

The mere numbers show the great importance of Spain as a destination visited by air; this kind of transport was the choice of almost $80 \%$ of tourists visiting the country in 2015 . The most significant airports as for the number of destinations were Barcelona-El Prat (almost 200) and Madrid-Barajas (similarly). Not far from these two hubs was Palma de Mallorca, connected with 167 different airports in the world. The other 4 airports also reached the number of over 100 different connections (Figure 5). The situation is different if one considers the number of countries 


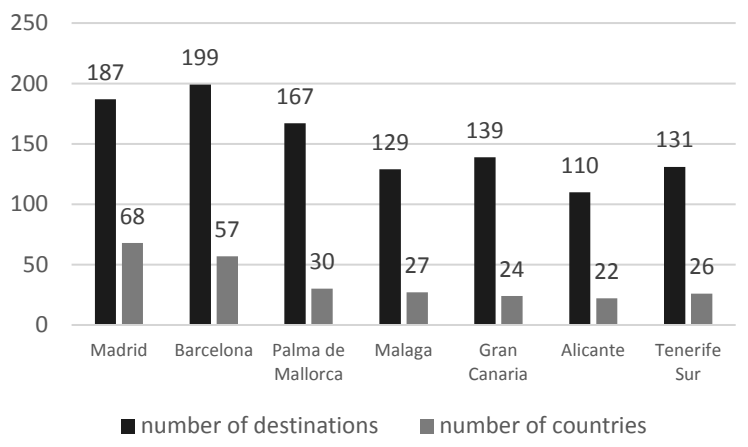

Figure 5. Number of destinations and countries connected with the main Spanish airports, 2015

Source: http://www.anea.es.

connected. Here again the most important airports were Madrid and Barcelona, with the average of 62 countries connected. For Palma de Mallorca, Malaga or Tenerife South, the number of connections was twice smaller.

The international tourist traffic to Spain is grouped into the following categories: 23 leading countries sending tourists (among them there is Poland), the rest of the EU, the rest of Europe, the rest of Americas, the African countries and the rest of the world. Taking into account this division, one can observe that two Spanish hubs connect Spain with every country present on the Spanish tourist market and that Palma de Mallorca or Malaga are connected with every country important for the Spanish tourist market. This is possible thanks to the air companies operating on the Spanish market. There are 83 airlines operating at the Barcelona-El Prat airport, 75 at MadridBarajas and 69 at the Palma de Mallorca airport. The average number of air companies that operate at the 7 major airports of Spain is 60, with the lowest number referring to Alicante-Elche ("only" 29 operating airlines).

\section{Conclusions}

It is difficult to overestimate the role that air transport plays in the Spanish tourism. The country, visited by more than 60 million international tourists in 2015 , owes its success to the air connections. This is bound with numerous factors. One of them is the peripheral location on the European continent. A country distant from the center of Europe, and especially its islands, would not have a chance for success without a comfortable and fast means of transport. The technological improvements were accompanied by changes in the creation of the tourist product. The most important element of the tourist package was the charter connection that made Spain an accessible destination for tourists from Western Europe in the 1960s. Another impulse was the development of LCCs, which revolutionized the Spanish tourist transport market and gained an important share. New destinations appeared on the tourist map of Spain that had earlier been less accessible for international and national tourists.

For now, it is difficult to imagine an abrupt change in the transport market. Tourism in Spain is based in $80 \%$ on air transport, which is the reason for its dynamic development. 


\section{Referencess}

Aguiló, E., Rey, B., Roselló, J., Torres, C.M. (2007). The impact of the post liberalization growth of LCCs on the tourism trends in Spain. Rivista di Politica Economica, 39-59.

ATAG (2005). The economic \& social benefits of air transport. Geneva: ATAG.

CNMC (2014). E/CNMC/0002/14 El sector aeroportuario en España: situacion actual y recomendaciones de liberalizacion.

http://estadisticas.tourspain.es.

http://www.aena.es.

Kaczmarska, A. (2014). Wybrane czynniki rozwoju turystyki. Studia Ekonomiczne, 176, 201-215.

Kowalczyk, A. (2001). Geografia turyzmu. Warszawa: Wydawnictwo Naukowe PWN.

Kowalczyk, A. (2013). Relacje zachodzące między rozwojem transportu lotniczego a rozwojem turystyki. In: R. Pawlusiński (ed.), Współczesne uwarunkowania i problemy rozwoju turystyki (pp. 61-72). Kraków: IGiGP UJ.

Kozak, M.W. (2009). Turystyka i polityka turystyczna a rozwój: między starym a nowym paradygmatem. Warszawa: Scholar.

Koźlak, A. (2008). Ekonomika transportu: Teoria i praktyka gospodarcza. Gdańsk: Wydawnictwo Uniwersytetu Gdańskiego.

Lareu, J.F. (1994). Turismo de masas y calidad de servicios. Edicion tercera ampliada. Palma de Mallorca: Gráficas Planisi.

Pender, L., Sharpley, R. (eds.) (2008). Zarządzanie turystyką. Warszawa: PWE.

Pietrzakowski, M. (2012). Rozwój współczesnego transportu lotniczego. Retrieved from: http://m.infobus.pl/rozwoj-wspolczesnego -transportu-lotniczego.

Pijet-Migoń, E. (2012). Zmiany rynku lotniczych przewozów pasażerskich w Polsce po akcesji do Unii Europejskiej. Rozprawy Naukowe Instytutu Geografii i Rozwoju Regionalnego Uniwersytetu Wrocławskiego, 25.

Rey, B., Myro, R., Galera, A. (2010). Effect of low-cost airlines on tourism in Spain. A dynamic panel data model. Journal of Air Transport Management, 30, 1-5.

UNWTO. (2000). Tourism Highlights 2000.

UNWTO. (2001). Tourism Highlights 2001.

UNWTO. (2002). Tourism Highlights 2002.

UNWTO. (2003). Tourism Highlights Edition 2003.

UNWTO. (2004). Tourism Highlights Edition 2004.

UNWTO. (2005). Tourism Highlights 2005 Edition.

UNWTO. (2006). Tourism Highlights 2006 Edition.

UNWTO. (2007). Tourism Highlights 2007 Edition.

UNWTO. (2008). Tourism Highlights 2008 Edition.

UNWTO. (2009). Tourism Highlights 2009 Edition.

UNWTO. (2010). Tourism Highlights 2010 Edition.

UNWTO. (2011). Tourism Highlights 2011 Edition.

UNWTO. (2012). Tourism Highlights 2012 Edition.

UNWTO. (2013). Tourism Highlights 2013 Edition.

UNWTO. (2014). Tourism Highlights 2014 Edition.

UNWTO. (2015). Tourism Highlights 2015 Edition.

UNWTO. (2016). Tourism Highlights 2016 Edition.

Wyrzykowski, J., Marak, J. (eds.) (2010). Turystyka w ujęciu interdyscyplinarnym. Wrocław: Wyższa Szkoła Handlowa.

Cite this article aS: Widawski, K., Oleśniewicz, P., Zaręba, A., Krzemińska, A. (2017). The role of airports in the tourist market development on the example of Spain. European Journal of Service Management, 4 (24), 23-74. DOI: 1.18276/ejsm.2017.24-10. 